\title{
A Research on Automation Diagonsis of Pattern Recognition in Stained HEP-2 Cells
}

\author{
C C Manju, M.Victor Jose
}

\begin{abstract}
Diagnosis of autoimmune diseases can be achieved via Indirect Immunofluorescence (IIF) images using human epithelial (HEp-2) cell as substrate in laboratory. The automation of this diagnosis method is still challenging because of using various liquids to fix the HEp-2 cells in the slides. Due to various fixation methods, nuclear morphology of cell suffers high variability. This survey reviews all the difficulties in the analysis and recognition of pattern recognition and surveys various image processing techniques which leads to the automation diagnosis. This work consist of advantages and disadvantages of various procedures. Eventually, comparison of their corresponding results are presented. I assure that this initial work may attract many medical image processing researchers to enter into this field.
\end{abstract}

Index Terms- autoimmune diagnostic; antinuclear antibodies; Pattern Recognition; HEp-2 cells.

\section{INTRODUCTION}

Computerized medical image processing plays a significant part in various fields of medicine such as diagnosis, prediction and monitoring. The present era shows keen interest with new technologies in clinical practice. [1] Modern medical technologies enforce demand for computational methods that enable practitioners to analyze large quantities of data in an efficient manner within short period of time. There is a substantial requirement for software tools which accelerate the microscopic image automating diagnose analysis to provide specific treatment for patients. Medical statistics shows that Autoimmune Diseases (AD) cause great damages with the population particularly for all age groups of women. [2] The exposure of $\mathrm{AD}$ in the tissues of human body is determined by conducting a test for the identification of antinuclear antibody (Human Epithelial Type 2 (HEp-2)) through antinuclear Antibody (ANA) test. Segregating HEp-2 fluorescence patterns in Ancillary Immunofluorescence (IIF) images is important for the declaration of autoimmune diseases. The present practitioner practices with human visual examination which is subjected to time efficiency. The testing of this coated stains is dependent on good laboratory practice and practitioner experience. An automated computer assisted diagnosis system rectifies the limitations of the current lab manual test method. The accuracy of the results will be high and more reliable.

Revised Manuscript Received on August 05, 2019.

C C Manju, Research Scholar, Department of Computer Science and Engineering, Noorul Islam Center for Higher Education,, Kumaracoil , Tamil nadu - 629180, India

Dr.M.Victor Jose, Associate Professor, Department of Computer science and Engineering, Noorul Islam Center for Higher Education, Kumaracoil , Tamil nadu - 629180, India
Various Autoimmune Diseases reveals different pattern in the Blood serum test called as ANA test. Based on the cell pattern, the $\mathrm{AD}$ can be diagnosed. The IIF microscopic image analysis seems to be very challengeable task because of bulk images. There is also a possibility for the variations in analysis which depends upon the experience and knowledge of the practitioners. So there arises the need for automatic diagnosis. Several techniques have been proposed in order to improve the quality of the IIF images, image segmentation and classification, color enhancement and Automatize image diagnosis

We have to dealt with lot of problems in automatized HEp-2 cell pattern based AD diagnosis like.

- $\quad$ The effective automatic Computer Aided Diagnosis system should observe the fluorescence microscopic IIF images based on the acquired fluorescence signal intensity. The strength of the signal can categorized as negative, intermediate or positive.

- It should overcome the straining style which affects the diagnosis of $\mathrm{AD}$ because of providing clear image results.

- $\quad$ The system segment the received IIF images and classify it by comparing cultured cells of HEp-2 cell line using pattern matching. According to the pattern type of fluorescence signal, the AD could be diagnosed by revealing the auto-antibody type.

This survey concentrates on the different methods of IIF image segmentation and classification. The various IIF image segmentation approaches are used for (i) the computerized segmentation of the HEp-2 cells (ii) the recognition of the mitotic cells in the slides (iii) the amount of intensity in fluorescence (iv) automated staining patterns classification. In particular, most of the recent efforts are focused on the latter task and the proposed classification schemes span the entire spectrum of machine learning (e.g.; SVM methods, Fuzzy learning methods, Transform methods, self-organizing random forests map method, vector learning, Tree based learning algorithms and multi kernel based learning systems). The fluorescent patterns are identified by the image spatial and statistical descriptors which is mainly attentive with morphological and textual features.

Even though they has wide range of latest research, the exact diagnosis of the pattern discovering can be leftover as a challengeable task. HEp-2 cell recognition Computer Aided Diagnosis System (CADS) has to face the following challenges.

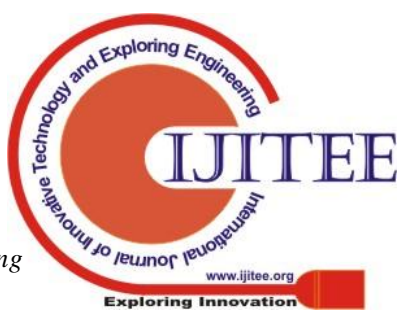


1. The Impact of IIF image segmentation of HEp-2 cells affects the accuracy of the AD diagnosis. This also affects the mitotic cells and fluorescence pattern categorization.

2. The more implicit variation exist in the HEp-2 cell segmentation. This is due to more staining patterns and the intensity levels which ensure the quality of image.

3. The possible generation of artifacts may happen due to irregular brightness and photo bleaching effect. The mitotic cells looks bright in some cell and dark in some cell.

4. The dependency relationship of cell causes issues in the segmentation phase.

Mainly all CADS approaches for IIF fluorescence HEp-2 cell image pattern analysis are evaluated based on the subsequent characteristics like resolution, contrast, noise, pattern recognition and accuracy. We can assume the segmentation and classification approach as to be efficient hinge on the posterior requirements.

1. The segmentation of fluorescence images should be very effective. Otherwise it leads to wrong justification from negative to intermediate or intermediate to positive. The segmentation should not be over or under beneficial to afford better accuracy.

2. The classification approaches lies with the result of classification accuracy.

3. The impact of noise or contrast level issues should be lessen.

The aim of this survey towards the CADS approach in classifying IIF images to find HEp-2 cells is to provide a well standard atomized method. In this process, various issues in segmentation and classification are analyzed. The different existing approaches with their merits and demerits are analyzed. It briefly explore the pattern recognizing of antinuclear antibody which causes AD to the humankind. The main motive of this survey is to direct a best CADS to protect the population from AD diseases.

This survey is well ordered as follows. The section II exhibits the previous work in segmentation and classification approaches of IIF fluorescence images. Section III write up the full characterization of the HEp-2 image dataset. The section IV exemplifies the implementation of classification and its applications. The section $\mathrm{V}$ views the results and discussion of various

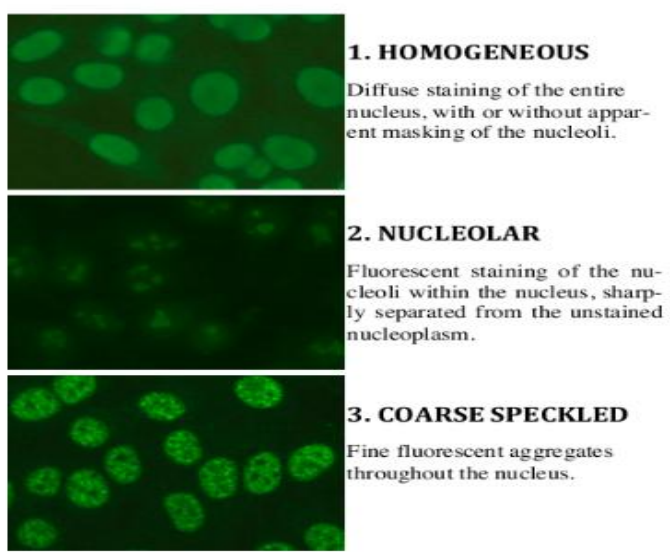

techniques. Finally, remarks of the HEp-2 cell pattern recognition are presented in section VI.

\section{TERMINOLOGIES USED IN THIS RESEARCH}

\section{Antinuclear Antibody Test (ANA):}

Generally the ANA test is conducted through the sample blood collected from patients. The blood serum is investigates whether the antibody is presence in the cell nuclei or not by analyzing the stains. This antibody is known as anti-nuclear antibody. Fluorescence techniques are familiar in point of detecting the antibodies in the cells.

\section{Antibodies:}

White blood cell (B type) generates antibodies which repel against the infectious organisms.

\section{Autoantibodies:}

Occasionally antibodies identify the normal protein as infectious and starts to fight against it. This is called as autoantibodies.

\section{Antinuclear Antibodies (ANA):}

Sometimes this Autoantibodies fight against the proteins of core nucleus within the cell. This is called as antinuclear antibodies.

\section{Autoimmune Diseases (AD):}

These autoantibodies fight against its tissues. This direct us for an autoimmune disease. Example for AD are lupus, scleroderma, Sjogren's syndrome and polymyositis/dermatomyositis.

\section{Patterns:}

The presence of ANA within the nuclei revels different patterns which is important for the determination o ANA .The presence of pattern may not directly represent the disease. But the particular disease could be related to that pattern. The six patterns of HEp-2 cell and their descriptions are indicated in Figure.1

Automatic Computer Aided Diagnosis system categorize HEp-2 specimen images into seven catalogs namely [3] homogeneous, speckled, nucleolar, centromere, golgi, nuclear membrane and mitotic spindle.

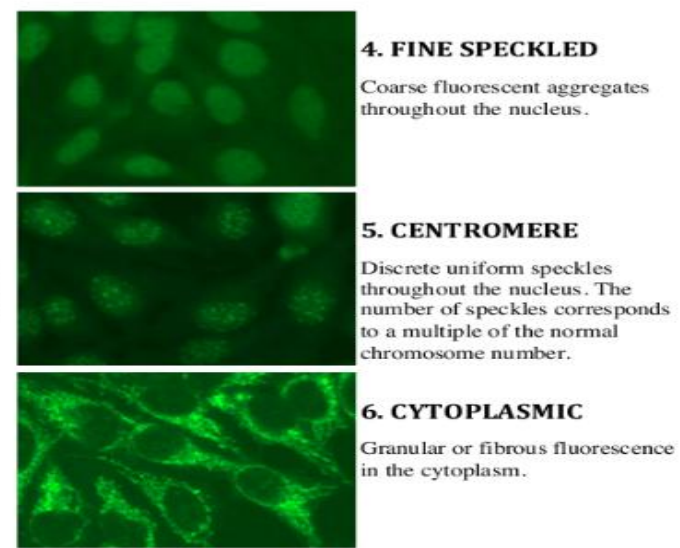

Figure 1: six types of staining patterns with positive and intermediate intensity levels. 
The pattern Centromere is analyzed by several discrete speckles $(\approx 40-60)$ scattered all over the interphase nuclei and symptomatically originated in the shortened nuclear chromatin all the while mitosis as a bar of conjunction with associated speckles.

The pattern Nucleolar is categorized by grouping enormous granules in the nucleoli of interphase cells which lean towards homogeneity, with less than six granules per cell. The pattern Homogeneous is studied by a drawn-out staining forth the interphase nuclei and staining forth the chromatin of mitotic cells. Fine Speckled pattern is described by a well granular nuclear staining of the interphase cell nuclei. Coarse Speckled pattern is studied by an uneven granular nuclear staining of the interphase cell nuclei. And finally Golgi pattern is considered as very difficult to identify.

\section{PHASES OF AUTOMATIC IMAGE PROCESSING}

\section{A.IIF fluorescence Image Normalization}

IIF fluorescence Image Normalization contributes an expressive role in segmentation and classification. The pixel intensity values are changed to the range of normal or sensed signal. The glare and dimension change of microscopic image impact poor classification result. The motivation of this preprocessing step is to attain stability in vigorous range for a group of concluded data, signals, or images directed toward avoiding mental diversion or lethargy. [3] Generally 120 grey-levels of contrast variation is preferable for positive identification. The grey scales from 80 to 100 becomes better for the interphase recognition. The image size should lies in the range of $45-130$ pixels. There are various reasons which affects the intensity of image signals. Sensor impulse noise effect degrade the pixel level from 4 to 8 disciplined to the location. The focus precision affects the basic properties of images. The preferred cell image size is $128 \times 128$ pixels. In order to attain the intensity level, green fluorescence is preferred. [4] The cell images are first transformed to grayscale by considering green channel. The lowest intensity at the bottom set to $1 \%$ of pixel values and highest intensity also with $1 \%$ of pixel value. Thus we can achieve intensity normalization. There are many image normalizing approaches for the fluorescence images. Uneven illumination and background signal are the common problems of Fluorescence images which varies with time. The calculations are done for background level in order to accomplish cellular signal and control the gain and camera offset. Cooper et al. [4] Proposed an approach to encounter brightness of spatial variations through sequential antagonistic and this outcome is split by the local average luminance by nonlinear normalization. This work used standard deviation to determine the shapes through spatial extension over which contrast is computed. Schwarz Fischer and Marr et al.[5] Partitioned the entire image into small images and identified the background textures. Every intensity distribution was grouped with the use of statistical method. From this time dependent resultant information, image gain was achieved. This is very effective method which overcome the impact of the noises in IIF fluorescence images.

\section{B.IIF fluorescence Image Segmentation}

Segmentation is the first step to understand the image in the automatic image processing. In this step, the image is breakdown into meaningful attributes. The automatic classification is chain process of segmentation which will be fail because of improper segmentation. The IIF fluorescence Image can be segmented based on cell level and specimen level. The cell level segmentation works along with quarantined mask. The cells in the interphase are segmented individually. So that the cell can be easily retrieved and matched with the patterns. The specimen level segmentation segment the complete image along with cell, mitosis and other objects. The partitioning of image should ensure objects, shapes, contours and curves of the images. These details could be emphasized using the texture, color and intensity properties of the image. The medical IIF fluorescence Image segmentation in analysis HEp-2 cells requires more centered knowledge with image segmentation. Positive intensity IIF images are greater in contrast as associated to intermediate images. Therefore, any segmentation algorithm for IIF images need to be designed carefully. . One draw-back common to most of the proposed approaches based on these methods is that the optimal system parameters are not invariant to image quality, thereby making them less robust. Significant efforts are required to develop efficient techniques for $\mathrm{HEp}-2$ cell segmentation from IIF images. Several image segmentation approaches were proposed for the fluorescence images. $A L$ Dulaimi and Banks et al. [6] used Geometric Active Contours (GACs) Morphological operations were implemented to guess the starting margin. Curve model was acquired with the use of GAC for the determination of cell boundary. This method was evaluated with six metrics and achieved good success rate. Zhou and Li et al.[7] proposed a thresholding approach by breaking the entire image into several sub images and applied a threshold analyzer to resolve the boundary. This research used deviation measuring approach to the partitioned images and estimated the overall specimen. Threshold approaches may not have local information of an image, this makes imaging artifacts as sensitive.

Huang et al.[8] enhanced the watershed procedure with more phases. The first phase detects the segmented outlines like man drawing and the next phase similarity score is identified to avoid over segmentation with a marker. This algorithm suffers with noise and contrast confliction. Thus there exist many automatic segmentation techniques for fluorescence images. But there is need to travel a long path for HEp-2 cell segmentation by overcoming the following limitations to achieve successful classification.

1. Various stains.

2. The different cell densities.

3. Data's Intricacy learnt from multiple wavelengths.

4. Image noise

5. Grouping and nature super imposed cells.

6. More number of cells per image. 


\section{IIF fluorescence Image Classification}

[9]The classification of HEp-2 cells in IIF images could be performed based on two levels. The first method apply the classification in cell level and the second with specimen level. The first method classifies every individual cell in a discrete manner for identifying HEp2 patterns. The covering mask of the cell will be available. Every IIF image is appended with a pattern marked label. This final prolonged cells major contribution. The second specimen level classification is the method of classifying the whole object instead of cell based analysis. It admire all the objects involved in the image. The cell level classification is best suited for some applications and specimen level classification is well suited for some type of application. For classification seems to be suitable because the analysis is preferred only within the nucleus. Several pattern matching classification algorithms have been proposed to overcome the limitations of IIF fluorescence Image Classification. Nigam and Vatsa et al. [10]analyzed various challenges and Proposed a two level descriptor for the classification of automated HEp-2 cell classification. First Laws features are extracted from the individual cells of interphase and the combined SVM classifier analyses the possibilities of classification. $X u$ and Sun et al.[11] applied fractal descriptors for the HEp-2 cell cataloguing. This project applied various fractal dimension for the cell pixel complexity and spatial distribution. This work implied morphological descriptor as well as textual descriptor and achieved $67 \%$ accuracy with the dataset. However since there are many limitations which should be overcome in this classification problem. The main problems are as follows.

1. Various observation without knowing morphological facts.

2. Lack of common best dataset to evaluate the various research work.

3. Image acquisition according to different criteria.

4. Different methods for the preparation of microscopic slides for antigenic substrate.

5. So many fixation methods shows different cell morphology and histological staining.

\section{CLASSIFICATION METHODS \& RESULTS}

To the beneficial of classifying HEp-2 cells, various protocols should be deployed with IIF segmentation data. The descriptive feature set of the image are applied with classifying algorithms to identify the best suited combination. Edge Border, Descriptor, Contour and Magnitude, Numerical, and Texture Features are the fundamental features of IIF image segmentation textures.

\section{A. Feature Set}

The feature set are denoted as the entities subjected to typify a cell image affording to a definite method. At hand we have three main categories to represent the feature set. Morphological features are response for the shape or particular nuclei identification of cell images using its fluorescent signals. Global texture descriptors direct to the determination could be based on the combination of the classification of HEp-2 cells in IIF images the cell level

comprehensive presence or wide-ranging scatter of the graylevels in the cell image. Local texture descriptors indicates the quarantined involvement of minor regions or pixel localities. This feature descriptors are investigated with experimental protocols.

\section{B. Classification protocols}

The following two main Classification protocols are stated in this survey.1. Contest cell level protocol 2. Samplebased cross-validation protocol.

\section{Contest cell level protocol:}

The dataset is categorized as training and the various classifying algorithms employ with the cell features of the image. The background of image contest will be zero and the features of the cell is retrieved in the segmentation section. The classification takes place in every individual cell. It may not inherit any information of the adjacent cells of the image. This protocol is used only to analyze the particular feature of the cell. If we need to consider the intensity of fluorescence to be analyzed, this protocol provides good support. But we need to be combine the other cell related information for better accuracy within the image.

\section{Sample based cross-validation:}

The requirement of adjacent cell contest information needed for the classification. This enforced cross validation approach which was based on leave-one-out procedure. All cells from the same specimen are collected to provide the assessment value. But every individual cell classification could be performed independently. This method is well suited when treating with large dataset in real time application.

\section{SUMMARY}

We surveyed the automated HEp-2 cell discovery approaches from the manual morphological ANA test to the recent research work going in this field. We tackled the problem with three stages. 1. Image preprocessing 2. Image Segmentation 3. Pattern recognition. We surveyed Segmentation process with following methods. Model based, Transform methods and various Feature extraction techniques such like Multiscale, Co-occurrence matrix and histogram approach. Various Classification approaches are surveyed like neural network approach, Fuzzy based approach and learning based approach. The various classification approaches tries to find a better optimal discovery mechanism. But the resultant accuracy is not still up to the mark. The common fixation method should be adopted which take care of the $\mathrm{AD}$ related antigens in the cell nucleoli. This makes the researchers to evaluate their approaches easily. [12]The morphological research results shows that Aldehyde fixatives safe guard the cell structures best contrast to the acetone fixatives publicized extraordinary deviations. All-inclusive review of the automated HEp-2 cell detection based approaches are presented in Table I. 
Table I Comprehensive Review Of Automated Hep-2 Cell Identification

\begin{tabular}{|c|c|c|c|c|c|}
\hline Technique & $\begin{array}{c}\text { Author } \\
\text { \& Ref } \\
\text { No. }\end{array}$ & $\begin{array}{l}\text { Ye } \\
\text { ar }\end{array}$ & Description & Advantages & Disadvantages \\
\hline \multicolumn{6}{|c|}{ IIF Image Preprocessing } \\
\hline $\begin{array}{l}\text { Various } \\
\text { preprocessi } \\
\text { ng } \\
\text { techniques } \\
\text { and CNN } \\
\text { classifiers } \\
\end{array}$ & $\begin{array}{l}\text { Rodrigu } \\
\text { es and } \\
\text { Naldi et } \\
\text { al [13] }\end{array}$ & $\begin{array}{l}20 \\
17\end{array}$ & $\begin{array}{l}\text { The dataset was applied to six } \\
\text { preprocessing steps and various } \\
\text { three CNN models was assessed } \\
\text { with different combination. }\end{array}$ & $\begin{array}{l}\text { 1. This work enforced the } \\
\text { importance of } \\
\text { preprocessing for } \\
\text { classification accuracy. }\end{array}$ & $\begin{array}{l}\text { 1. Deploying CNN is } \\
\text { expensive. }\end{array}$ \\
\hline \multicolumn{6}{|c|}{ IIF Image Segmentation } \\
\hline $\begin{array}{l}\text { active } \\
\text { contour } \\
\text { method }\end{array}$ & $\begin{array}{l}\text { Merone } \\
\text { and } \\
\text { Soda } \\
{[14]}\end{array}$ & $\begin{array}{l}20 \\
16\end{array}$ & $\begin{array}{l}\text { Edge detection was performed } \\
\text { for every individual cell in the } \\
\text { image without gradient. This } \\
\text { aspect supports various staining } \\
\text { styles and various fluorescence } \\
\text { intensities of HEp- } 2 \text { cells. }\end{array}$ & $\begin{array}{l}\text { 1. The weak fluorescence } \\
\text { intensity of cell edges } \\
\text { may not disturb in } \\
\text { classification. } \\
\text { 2. This method will not } \\
\text { divide the overlapping } \\
\text { cells }\end{array}$ & $\begin{array}{l}\text { The clustered cells } \\
\text { seems to be difficult } \\
\text { at the time of cell } \\
\text { level classification. }\end{array}$ \\
\hline $\begin{array}{l}\text { Wavelet } \\
\text { transformati } \\
\text { on for } \\
\text { segmentatio } \\
n\end{array}$ & $\begin{array}{l}\text { Rosdi } \\
\text { and May } \\
\text { et al. } \\
{[15]}\end{array}$ & $\begin{array}{l}20 \\
16\end{array}$ & $\begin{array}{l}\text { Statistical features were extracted } \\
\text { for the related metrics of images. } \\
\text { The cell features are transformed } \\
\text { to wavelet signals. }\end{array}$ & $\begin{array}{l}\text { 1. } 50 \text { features are } \\
\text { extracted from each } \\
\text { image when applying } \\
\text { DWT. } \\
\text { 2. No need of complex } \\
\text { calculation. } \\
\text { 3. High efficiency and } \\
\text { effective in extracting the } \\
\text { data. } \\
\text { 4. The best suited wavelet } \\
\text { function could be selected } \\
\text { for the pattern analysis } \\
\text { among the several } \\
\text { wavelet functions. }\end{array}$ & $\begin{array}{l}\text { 1.Computationally } \\
\text { intensive } \\
\text { 2. Discretization } \\
\text { cells segmentation. } \\
\text { 3.It is not invariant } \\
\text { with the translation }\end{array}$ \\
\hline $\begin{array}{l}\text { Spatial and } \\
\text { texture } \\
\text { based cell } \\
\text { segmentatio } \\
\text { n. }\end{array}$ & $\begin{array}{l}\text { Prasath } \\
\text { et al [9] }\end{array}$ & $\begin{array}{l}20 \\
16\end{array}$ & $\begin{array}{l}\text { Multi scale feature bank to } \\
\text { collect the spatial information } \\
\text { about the cell features. And } \\
\text { classifiers were implemented. }\end{array}$ & $\begin{array}{l}\text { 1. This approach worked } \\
\text { along with cell } \\
\text { segmentation and cell and } \\
\text { specimen level classifiers. } \\
\text { 2. High accuracy with } \\
\text { complex cases. }\end{array}$ & $\begin{array}{l}\text { 1. uncertainty and } \\
\text { instability of pixel } \\
\text { data } \\
\text { 2. Very difficult for } \\
\text { the implementation. }\end{array}$ \\
\hline $\begin{array}{l}\text { Fuzzy } \\
\text { clustering } \\
\text { for cell } \\
\text { segmentatio } \\
\text { n }\end{array}$ & $\begin{array}{l}\text { Roy and } \\
\text { Maji et } \\
\text { al[16] }\end{array}$ & $\begin{array}{l}20 \\
16\end{array}$ & $\begin{array}{l}\text { Pixel level clustering has been } \\
\text { done based on fuzzy set } \\
\text { clustering algorithm. The } \\
\text { threshold value identifies the } \\
\text { clusters based on centroid value. }\end{array}$ & $\begin{array}{l}\text { 1. It mainly focused the } \\
\text { noise in between the } \\
\text { pixels. } \\
\text { 2. Image artifacts were } \\
\text { identified which was } \\
\text { caused by coating of } \\
\text { instruments. } \\
\text { 3. It handled uncertainty, } \\
\text { incompleteness and } \\
\text { vagueness in cluster. } \\
\text { 4. Ambiguity through } \\
\text { overlapping cells could } \\
\text { be easily solved. }\end{array}$ & $\begin{array}{l}\text { 1. The sum } \\
\text { constraints for the } \\
\text { row must be equal to } \\
\text { one. } \\
\text { 2. Very sensitive for } \\
\text { the data initialization } \\
\text { process. }\end{array}$ \\
\hline
\end{tabular}




\begin{tabular}{|c|c|c|c|c|c|}
\hline $\begin{array}{l}\text { key } \\
\text { challenges } \\
\text { in Analysis } \\
\text { and } \\
\text { Recognition } \\
\text { of IIF } \\
\text { Images }\end{array}$ & $\begin{array}{l}\text { Foggia } \\
\text { et al [17] }\end{array}$ & $\begin{array}{l}20 \\
16\end{array}$ & $\begin{array}{l}\text { Overall survey studied IIF image } \\
\text { preprocessing, segmentation, } \\
\text { classification, } \\
\text { protocols and various result } \\
\text { oriented analysis. }\end{array}$ & $\begin{array}{l}1 \text { Encourage the } \\
\text { researchers by showing a } \\
\text { path to attain the goal. } \\
\text {. }\end{array}$ & \\
\hline $\begin{array}{l}\text { marker - } \\
\text { controlled } \\
\text { water shed } \\
\text { method for } \\
\text { IIF image } \\
\text { segmentatio } \\
\mathrm{n}\end{array}$ & $\begin{array}{l}\text { Tonti } \\
\text { and } \\
\text { Cataldo } \\
\text { et al.[18] }\end{array}$ & $\begin{array}{l}20 \\
15\end{array}$ & $\begin{array}{l}\text { Segmentation could be done with } \\
\text { multiple iterations of water shed } \\
\text { apply. So that high and low level } \\
\text { intensity can be easily identified. }\end{array}$ & $\begin{array}{l}\text { 1. This method mainly } \\
\text { focused the normalization } \\
\text { process by fuzzy C- } \\
\text { means alg. } \\
2 \text {. The accuracy and } \\
\text { security of segmentation } \\
\text { improved efficiently. }\end{array}$ & $\begin{array}{l}\text { 1. It suggested } \\
\text { manual } \\
\text { morphological } \\
\text { improvement with } \\
\text { data slides. }\end{array}$ \\
\hline \multicolumn{6}{|c|}{ IIF Image Pattern Classification } \\
\hline $\begin{array}{l}\text { Secondary } \\
\text { image } \\
\text { features } \\
\text { analysis }\end{array}$ & $\begin{array}{l}\text { Larsen } \\
\text { et al [19] }\end{array}$ & $\begin{array}{l}20 \\
14\end{array}$ & $\begin{array}{l}\text { A new index is maintained for } \\
\text { the shape feature. Spatial } \\
\text { decompose and reconstruction } \\
\text { was based on donut shaped } \\
\text { pooling method. }\end{array}$ & $\begin{array}{l}\text { 1. Computation } \\
\text { complexity is very low. } \\
\text { 2. High level of accuracy } \\
\text { achieved. } \\
\text { 3. It is very fast to extract } \\
\text { the features. }\end{array}$ & $\begin{array}{l}\text { 1. Confused with } \\
\text { training and testing. }\end{array}$ \\
\hline $\begin{array}{l}\text { Micro } \\
\text { structure } \\
\text { based } \\
\text { image pixel } \\
\text { constructio } \\
\mathrm{n}\end{array}$ & $\begin{array}{l}\text { Han and } \\
\text { Wang et } \\
\text { al. [20] }\end{array}$ & $\begin{array}{l}20 \\
14\end{array}$ & $\begin{array}{l}\text { Estimation of probability from } \\
\text { local Textron's to higher level } \\
\text { macrostructure of image features. }\end{array}$ & $\begin{array}{l}\text { 1. Probability adaptable } \\
\text { model search all the } \\
\text { possibilities. } \\
\text { 2. Very } \\
\text { computational cost. } \\
\text { 3. The change of spatial } \\
\text { resolution supports to } \\
\text { exhibit the textures in the } \\
\text { preferable scale., }\end{array}$ & $\begin{array}{lr}1 . \quad \text { Very } & \text { slow } \\
\text { execution because of } \\
\text { analyzing } \\
\text { possibilities. } \\
2 . \quad \text { all } \\
\text { complexity } \\
\text { occupies } \\
\text { memory. }\end{array}$ \\
\hline $\begin{array}{l}\text { Texture } \\
\text { descriptors } \\
\text { based on } \\
\text { fuzzy } \\
\text { texture } \\
\text { features }\end{array}$ & $\begin{array}{l}\text { Schaefer } \\
\text { and } \\
\text { Doshi } \\
\text { [21] }\end{array}$ & $\begin{array}{l}20 \\
16\end{array}$ & $\begin{array}{l}\text { Fuzzy LBP descriptors to extract } \\
\text { texture features which coupled } \\
\text { with SVM classification. }\end{array}$ & $\begin{array}{l}\text { 1. Inherent noised were } \\
\text { eliminated. } \\
\text { 2. SVM based easy } \\
\text { classification. } \\
\text { 3. Rotation of textures } \\
\text { features can be easily } \\
\text { analyzed. }\end{array}$ & $\begin{array}{l}\text { 1. It doesn't provide } \\
\text { enough information } \\
\text { for } \\
\text { descriptors. }\end{array}$ \\
\hline $\begin{array}{l}\text { Single to } \\
\text { Multiresolu } \\
\text { tion } \\
\text { Texture } \\
\text { Information }\end{array}$ & $\begin{array}{l}\text { Qi and } \\
\text { Zhao et } \\
\text { al. [22] }\end{array}$ & $\begin{array}{l}20 \\
17\end{array}$ & $\begin{array}{l}\text { Constructing pixel level regional } \\
\text { information starting from Root } \\
\text { SIFT and move upward for } \\
\text { further search in the feature } \\
\text { space using improved Fisher } \\
\text { vector model. }\end{array}$ & $\begin{array}{l}\text { 1. Hybrid approach which } \\
\text { combines texture and } \\
\text { shapes. } \\
2 \text { Reconstruct 3D } \\
\text { surface geometry from } \\
\text { texture } \\
\text { Information. } \\
\text { 3. Multiresolution } \\
\text { approach appears more } \\
\text { effective compared to } \\
\text { single resolution analysis. }\end{array}$ & $\begin{array}{l}\text { 1. Blocking effect at } \\
\text { the time of high } \\
\text { compression of } \\
\text { images. } \\
2 . \text { This approach } \\
\text { works only with } \\
\text { frequency resolution } \\
\text { and no time } \\
\text { resolution. }\end{array}$ \\
\hline
\end{tabular}




\begin{tabular}{|c|c|c|c|c|c|}
\hline $\begin{array}{l}\text { Distributed } \\
\text { learning } \\
\text { based on } \\
\text { Dictionary } \\
\text { and sub } \\
\text { vector }\end{array}$ & $\begin{array}{l}\text { Monaje } \\
\text { mi and } \\
\text { Ensafi } \\
\text { et al.[23] }\end{array}$ & $\begin{array}{l}20 \\
16\end{array}$ & $\begin{array}{l}\text { Extracted SIFT features were } \\
\text { learnt using DDL dictionary. } \\
\text { Then the sparse codes are } \\
\text { grouped with pyramid matching. }\end{array}$ & $\begin{array}{l}1 \text { This method is useful } \\
\text { for unsupervised } \\
\text { problems like } \\
\text { reconstructing the image } \\
\text { pixels and also for } \\
\text { supervised problems like } \\
\text { extracting features from } \\
\text { the images. } \\
\text { 2. Image reconstruction is } \\
\text { very easy with this } \\
\text { approach. }\end{array}$ & $\begin{array}{l}\text { 1. It is } \\
\text { computationally } \\
\text { expensive and time } \\
\text { consuming task. } \\
2 . \quad \text { Very slow } \\
\text { technique. }\end{array}$ \\
\hline $\begin{array}{l}\text { Learning } \\
\text { approach } \\
\text { from lower } \\
\text { to higher } \\
\text { textual } \\
\text { feature } \\
\text { deviation. }\end{array}$ & $\begin{array}{l}\text { Lei and } \\
\text { Han et al } \\
{[24]}\end{array}$ & $\begin{array}{l}20 \\
17\end{array}$ & $\begin{array}{l}\text { Cross-modal transfer learning } \\
\text { strategy involved the learning } \\
\text { process from low level semantic } \\
\text { feature to higher level semantic } \\
\text { features. }\end{array}$ & $\begin{array}{l}\text { 1. Multiple scales along } \\
\text { with DNS lifts the } \\
\text { performance. } \\
\text { 2. It solved the memory } \\
\text { issues which exist before. }\end{array}$ & $\begin{array}{l}\text { 1. DRS suffers for } \\
\text { optimal architecture } \\
\text { when reconstruction } \\
\text { requires. } \\
\text { 2. It provides } \\
\text { different } \\
\text { performance for } \\
\text { different data set. }\end{array}$ \\
\hline $\begin{array}{l}\text { Auto } \\
\text { encoding } \\
\text { introduced } \\
\text { with } \\
\text { traditional } \\
\text { CNN }\end{array}$ & $\begin{array}{l}\text { Liu and } \\
\mathrm{Xu} \text { et al } \\
{[25]}\end{array}$ & $\begin{array}{l}20 \\
17\end{array}$ & $\begin{array}{l}\text { DACN handled the two joint } \\
\text { network with single auto } \\
\text { encoding method which dealt } \\
\text { with classification error and } \\
\text { image reconstruction error. }\end{array}$ & $\begin{array}{l}\text { 1. Accuracy is achieved. } \\
\text { 2. Reconstruction of } \\
\text { images is easy. }\end{array}$ & $\begin{array}{l}\text { 1. It Need a large } \\
\text { dataset for the } \\
\text { evaluation. } \\
\text { 2. It suffers with } \\
\text { heterogeneous } \\
\text { metrics. } \\
\text { 3. Suffers with } \\
\text { negative images. }\end{array}$ \\
\hline $\begin{array}{l}\text { Multiple } \\
\text { kernel } \\
\text { learning } \\
\text { from binary } \\
\text { texture } \\
\text { features }\end{array}$ & $\begin{array}{l}\text { Schaefer } \\
\text { and } \\
\text { Doshi et } \\
\text { al[26] }\end{array}$ & $\begin{array}{l}20 \\
16\end{array}$ & $\begin{array}{l}\text { Multiple kernel learning } \\
\text { deployed in local binary pattern } \\
\text { (LBP) texture features. }\end{array}$ & $\begin{array}{l}\text { 1. Optimal combination } \\
\text { of similarity feature } \\
\text { learning. } \\
\text { 2. Good learning } \\
\text { constraints and Non- } \\
\text { linear observation. } \\
\text { 3.Different data formats } \\
\text { can be used in the same } \\
\text { formulation }\end{array}$ & $\begin{array}{l}\text { 1.Incomprehensibilit } \\
\text { y } \\
\text { 2. The selection of } \\
\text { the appropriate } \\
\text { kernel to solve a } \\
\text { problem is tricky } \\
\text { 3. No simple } \\
\text { generalization to } \\
\text { multi-class }\end{array}$ \\
\hline $\begin{array}{l}\text { Classificati } \\
\text { on using } \\
\text { decision } \\
\text { binary tree } \\
\text { structure }\end{array}$ & $\begin{array}{l}\text { Divya } \\
\text { and } \\
\text { Subrama } \\
\text { niam et } \\
\text { al[27] }\end{array}$ & $\begin{array}{l}20 \\
16\end{array}$ & $\begin{array}{l}\text { The image features were adopted } \\
\text { for the binary tree prediction. It } \\
\text { involved both static and contest } \\
\text { level features. }\end{array}$ & $\begin{array}{l}\text { 1. Easy to use and } \\
\text { efficient. } \\
\text { 22. Easy interpretation } \\
\text { and understandable rules } \\
\text { could be formed. } \\
\text { 3. Independent tree size } \\
\text { nature makes it as } \\
\text { suitable for large } \\
\text { databases }\end{array}$ & $\begin{array}{l}\text { 1. Instability. } \\
2 . \\
\text { comparison. }\end{array}$ \\
\hline $\begin{array}{l}\text { hierarchical } \\
\text { verification } \\
\text { of Sub class } \\
\text { features }\end{array}$ & $\begin{array}{l}\text { Gupta et } \\
\text { al[28] }\end{array}$ & $\begin{array}{l}20 \\
16\end{array}$ & $\begin{array}{l}\text { Extracted class-specific features } \\
\text { of each class were integrated } \\
\text { with SVM classifier. }\end{array}$ & $\begin{array}{l}\text { 1.SVM moves the } \\
\text { choices with Non- } \\
\text { parametric and works } \\
\text { locally } \\
\text { 2. It provide a unique } \\
\text { solution, like convex. }\end{array}$ & $\begin{array}{l}\text { 1. Due to non- } \\
\text { parametric measures, } \\
\text { transparency of } \\
\text { results suffers. }\end{array}$ \\
\hline
\end{tabular}




\begin{tabular}{|c|c|c|c|c|c|}
\hline $\begin{array}{l}\text { Roadmap } \\
\text { for } \\
\text { performanc } \\
\text { e evaluation } \\
\text { of } \\
\text { algorithms } \\
\text { for IIF } \\
\text { image } \\
\text { analysis }\end{array}$ & $\begin{array}{l}\text { Foggia } \\
\text { and } \\
\text { Percann } \\
\text { ella et } \\
\text { al. [29] }\end{array}$ & $\begin{array}{l}20 \\
13\end{array}$ & $\begin{array}{l}\text { Various segmentation issues and } \\
\text { causes. Various classification } \\
\text { problems and directions. Various } \\
\text { experimental protocols used to } \\
\text { assess the methods. }\end{array}$ & $\begin{array}{l}\text { 1. A clear roadmap for } \\
\text { the evaluation of HEp- } 2 \\
\text { cell recognition. }\end{array}$ & \\
\hline $\begin{array}{l}\text { Multiple } \\
\text { Kernel } \\
\text { Learning } \\
\text { using } \\
\text { pyramid } \\
\text { cell } \\
\text { constructio } \\
\text { n matching }\end{array}$ & $\begin{array}{l}\text { Wiliem } \\
\text { et al.[30] }\end{array}$ & $\begin{array}{l}20 \\
14\end{array}$ & $\begin{array}{l}\text { CPM descriptor collectively } \\
\text { adopted with multiple kernel } \\
\text { learning. The positive work of } \\
\text { SPM and DR descriptors were } \\
\text { included in this work. }\end{array}$ & $\begin{array}{l}\text { 1. It has the advantage of } \\
\text { visual vocabulary. } \\
\text { 2. Multiple resolution in } \\
\text { supervised manner. }\end{array}$ & 1. Very slow. \\
\hline $\begin{array}{l}\text { Local } \\
\text { binary } \\
\text { pattern } \\
\text { combined } \\
\text { with SVM }\end{array}$ & $\begin{array}{l}\text { Nosaka } \\
\text { and } \\
\text { Fukui et } \\
\text { al[31] }\end{array}$ & $\begin{array}{l}20 \\
14\end{array}$ & $\begin{array}{l}\text { The binary pixels are combined } \\
\text { to get RIC-LBP image feature } \\
\text { which further classified by SVM. }\end{array}$ & $\begin{array}{l}\text { 1. Local binary pattern is } \\
\text { very tolerant to noise of } \\
\text { the images. }\end{array}$ & $\begin{array}{l}\text { 1. LBP produce very } \\
\text { long histogram. }\end{array}$ \\
\hline $\begin{array}{l}\text { Intensity of } \\
\text { fluorescenc } \\
\text { e signal is } \\
\text { organized } \\
\text { hierarchical } \\
\text { ly. }\end{array}$ & $\begin{array}{l}\text { Shen } \\
\text { and lin } \\
\text { et al[32] }\end{array}$ & $\begin{array}{l}20 \\
14\end{array}$ & $\begin{array}{l}\text { Ordered Intensity features were } \\
\text { structured and worked along with } \\
\text { bag of words (BOW). Then } \\
\text { dictionary based pattern pooling } \\
\text { is analyzed. }\end{array}$ & $\begin{array}{l}\text { 1. It is rotation invariant. } \\
2 . \text { High discriminative } \\
\text { ability. }\end{array}$ & $\begin{array}{l}\text { 1.Instabilities in } \\
\text { regions of low } \\
\text { variance } \\
\text { insensitivity in } \\
\text { regions } \\
\text { intensities } \\
\text { 2.BOW ignores the } \\
\text { spatial relationships } \\
\text { among the patches, }\end{array}$ \\
\hline
\end{tabular}

\section{CONCLUSION AND FUTURE WORK}

The main aim of this survey is to build a state-of-the-art automated system to detect HEp-2 cells in the fluorescence images into three classes Positive, Intermediate and Negative. In this work, Automated HEp-2 cell detection methodologies along with various patterns and the challenges were surveyed. Initial work on this topic concentrated ANA test related information and the basic terminologies which may help the new researcher in this area. On account of problems present in IIF stains, Image preprocessing, image segmentation and image classifications are surveyed. The next section represent the experiment protocols which should be followed to implement new approaches. The various Techniques are categorized into various forms in preceding tabulations. The tabulations enhance the ideas about the method, its pros, and cons of the various types of approaches in automated detection of HEp-2 cells. The limitations observed from the survey exhibits that still there is a need to walk for a long distance in this particular research field. This survey analyzed previous IIF image segmentation and classification issues and suggested the requirement of better accuracy. It emphasize the cell level classification of mitotic cells. This may prevent the people from Autoimmune Diseases which is one among the top ten death diseases. In future work we decided to develop a deep convolution network based classification approach and make them to provide higher accuracy with common efficient manner.

\section{REFERENCES}

1 M. I. Razzak, S. Naz, and A. Zaib, "Deep Learning for Medical Image Processing: Overview, Challenges and the Future," in Classification in BioApps, ed: Springer, 2018, pp. 323-350.

2 A. Wiliem, Y. Wong, C. Sanderson, P. Hobson, S. Chen, and B. C. Lovell, "Classification of human epithelial type 2 cell indirect immunofluoresence images via codebook based descriptors," in Applications of Computer Vision (WACV), 2013 IEEE Workshop on, 2013, pp. 95-102.

3 V. Snell, W. Christmas, and J. Kittler, "HEp-2 fluorescence pattern classification," Pattern Recognition, vol. 47, pp. 2338-2347, 2014.

4 E. A. Cooper, "A normalized contrast-encoding model exhibits bright/dark asymmetries similar to early visual neurons," Physiological reports, vol. 4, p. e12746, 2016.

5 M. Schwarzfischer, C. Marr, J. Krumsiek, P. Hoppe, T. Schroeder, and F. Theis, "Efficient fluorescence image normalization for time lapse movies," Proc. Microscopic Image Analysis with Applications in Biology, vol. 5, 2011.

6 A.-D. Khamael, J. Banks, I. Tomeo-Reyes, and V. Chandran, "Automatic segmentation of HEp-2 cell Fluorescence microscope images using level set method via geometric active contours," in Pattern Recognition (ICPR), 2016 23rd International Conference on, 2016, pp. 81-83. 
7 X. Zhou, Y. Li, and L. Shen, "A novel adaptive local thresholding approach for segmentation of HEp-2 cell images," in Signal and Image Processing (ICSIP), IEEE International Conference on, 2016, pp. 174-178.

8 Y.-L. Huang, C.-W. Chung, T.-Y. Hsieh, and Y.-L. Jao, "Outline detection for the HEp-2 cell in indirect immunofluorescence images using watershed segmentation," in Sensor Networks, Ubiquitous and Trustworthy Computing, 2008. SUTC'08. IEEE International Conference on, 2008, pp. 423-427.

9 V. S. Prasath, Y. M. Kassim, Z. A. Oraibi, J.-B. Guiriec, A. Hafiane, G. Seetharaman, et al., "HEp-2 cell classification and segmentation using motif texture patterns and spatial features with random forests," in Pattern Recognition (ICPR), 2016 23rd International Conference on, 2016, pp. 90-95.

10 I. Nigam, S. Agrawal, R. Singh, and M. Vatsa, "Revisiting HEp-2 Cell Image Classification," IEEE Access, vol. 3, pp. 3102-3113, 2015.

11 R. Xu, Y. Sun, Z. Yang, B. Song, and X. Hu, "The classification of HEp-2 cell patterns using fractal descriptor," IEEE transactions on nanobioscience, vol. 14, pp. 513-520, 2015.

12 D. Hahm and U. Anderer, "Establishment of HEp-2 cell preparation for automated analysis of ANA fluorescence pattern," Cytometry Part A, vol. 69, pp. 178-181, 2006.

13 L. F. Rodrigues, M. C. Naldi, and J. F. Mari, "Exploiting Convolutional Neural Networks and preprocessing techniques for HEp-2 cell classification in immunofluorescence images," in Graphics, Patterns and Images (SIBGRAPI), 2017 30th SIBGRAPI Conference on, 2017, pp. 170-177.

14 M. Merone and P. Soda, "On using active contour to segment HEp-2 cells," in Computer-Based Medical Systems (CBMS), 2016 IEEE 29th International Symposium on, 2016, pp. 118-123.

15 N. A. M. Rosdi, Z. May, I. Faye, and M. Nasir, "Hep-2 cell feature extraction using wavelet and independent component analysis," in Industrial Electronics \& Applications (ISIEA), 2014 IEEE Symposium on, 2014, pp. 36-41.

16 S. Roy and P. Maji, "A modified rough-fuzzy clustering algorithm with spatial information for hep-2 cell image segmentation," in Bioinformatics and Biomedicine (BIBM), 2016 IEEE International Conference on, 2016, pp. 383-388.

17 P. Foggia, G. Percannella, A. Saggese, and M. Vento, "Pattern recognition in stained hep-2 cells: Where are we now?," Pattern Recognition, vol. 47, pp. 2305-2314, 2014.

18 S. Tonti, S. Di Cataldo, A. Bottino, and E. Ficarra, "An automated approach to the segmentation of HEp-2 cells for the indirect immunofluorescence ANA test," Computerized Medical Imaging and Graphics, vol. 40, pp. 62-69, 2015.

19 A. B. L. Larsen, J. S. Vestergaard, and R. Larsen, "HEp2 cell classification using shape index histograms with donut-shaped spatial pooling," IEEE transactions on medical imaging, vol. 33, pp. 1573-1580, 2014.

20 X.-H. Han, J. Wang, G. Xu, and Y.-W. Chen, "Highorder statistics of microtexton for hep-2 staining pattern classification," IEEE Transactions on Biomedical Engineering, vol. 61, pp. 2223-2234, 2014.

21 G. Schaefer and N. P. Doshi, "Effective classification of HEp-2 cells using fuzzy texture descriptors," in Fuzzy Systems (FUZZ-IEEE), $2016 \quad$ IEEE International Conference on, 2016, pp. 1248-1252.

22 X. Qi, G. Zhao, C.-G. Li, J. Guo, and M. Pietikäinen, "HEp-2 Cell Classification via Combining Multiresolution Co-Occurrence Texture and Large
Region Shape Information," IEEE journal of biomedical and health informatics, vol. 21, pp. 429-440, 2017.

23 S. Monajemi, S. Ensafi, S. Lu, A. A. Kassim, C. L. Tan, S. Sanei, et al., "Classification of HEp-2 cells using distributed dictionary learning," in Signal Processing Conference (EUSIPCO), 2016 24th European, 2016, pp. 1163-1167.

24 H. Lei, T. Han, W. Huang, J. Y. Kuo, Z. Yu, X. He, et al., "Cross-Modal Transfer Learning for HEp-2 Cell Classification Based on Deep Residual Network," in 2017 IEEE International Symposium on Multimedia (ISM), 2017, pp. 465-468.

25 J. Liu, B. Xu, L. Shen, J. Garibaldi, and G. Qiu, "HEp-2 cell classification based on a Deep AutoencodingClassification convolutional neural network," in Biomedical Imaging (ISBI 2017), 2017 IEEE 14th International Symposium on, 2017, pp. 1019-1023.

26 H. Cai and L. Cui, "MultiGranular: An effective Service Composition Infrastructure for Multi-tenant Service Composition," International Journal of Multimedia and Ubiquitous Engineering, vol. 9, pp. 171-182, 2014.

27 B. Divya, K. Subramaniam, and H. Nanjundaswamy, "HEp-2 cell classification using binary decision tree approach," in Biomedical Engineering and Sciences (IECBES), 2016 IEEE EMBS Conference on, 2016, pp. 507-512.

28 V. Gupta, K. Gupta, A. Bhavsar, and A. K. Sao, "Hierarchical classification of HEp-2 cell images using class-specific features," in Visual Information Processing (EUVIP), 2016 6th European Workshop on, 2016, pp. 16.

29 P. Foggia, G. Percannella, P. Soda, and M. Vento, "Benchmarking HEp-2 cells classification methods," IEEE transactions on medical imaging, vol. 32, pp. 1878-1889, 2013

30 A. Wiliem, C. Sanderson, Y. Wong, P. Hobson, R. F. Minchin, and B. C. Lovell, "Automatic classification of human epithelial type 2 cell indirect immunofluorescence images using cell pyramid matching," Pattern Recognition, vol. 47, pp. 2315-2324, 2014.

31 R. Nosaka and K. Fukui, "HEp-2 cell classification using rotation invariant co-occurrence among local binary patterns," Pattern Recognition, vol. 47, pp. 2428-2436, 2014.

32 L. Shen, J. Lin, S. Wu, and S. Yu, "HEp-2 image classification using intensity order pooling based features and bag of words," Pattern Recognition, vol. 47, pp. 2419-2427, 2014. 